\title{
Distribution and diversity of alternate hosts of Maruca vitrata Fabricius in three West African countries
}

\author{
Prince Christopher Addae ${ }^{1} \cdot$ Y. Anani Bruce ${ }^{2}$. lliyasu M. Utono ${ }^{3} \cdot$ Mumuni Abudulai $^{4} \cdot$ Fousseni Traore $^{5}$. \\ Mohammad F. Ishiyaku ${ }^{3}$. Rabiu S. Adamu ${ }^{3}$. Ahmed Seidu ${ }^{4}$ Benoît J. Batieno ${ }^{5}$. Onyekachi Francis Nwankwo ${ }^{1}$. \\ Malick N. Ba ${ }^{10}$. Gloria A. Adazebra ${ }^{4}$. Jean Baptiste Tignegre ${ }^{11}$. Clémentine L. Dabiré-Binso ${ }^{5}$. Joseph E. Huesing ${ }^{6}$. \\ Richard L. Hellmich ${ }^{7} \cdot$ Barry R. Pittendrigh $^{8} \cdot$ Manuele Tamò $^{9}$
}

Received: 5 June 2019 / Accepted: 14 January 2021 / Published online: 29 April 2021

(c) The Author(s) 2021

\begin{abstract}
The evolution of resistance to the Bacillus thuringiensis $(B t)$ toxins by insect pests is a major threat to $B t$ technology. However, the rate of resistance can be slowed with appropriate integrated insect resistance management (IRM) strategies. Surveys were conducted to identify alternate host species for Maruca vitrata (commonly called the legume pod borer or Maruca) that could serve as refuges for Pod-Borer Resistant (PBR) cowpea in three West African countries (Ghana, Nigeria, and Burkina Faso). Survey sites included 25 in northern Ghana, 44 in northern Nigeria, and 52 in north-central and southwestern Burkina Faso. Alternate hosts of Maruca identified from plant species belonging to the Fabaceae family that showed signs of Maruca damage on cowpea tissues were collected and dissected. Larvae that were found during these dissections were reared to adult moths in the laboratory then identified to species. The alternate host plants including species of Crotolaria, Sesbania, Tephrosia, and Vigna were the most frequently encountered among sites and locations. Flowering and podding of these plants overlapped with flowering and podding of the nearby $(\sim 200 \mathrm{~m})$ cowpea crop. Abundance of these wild hosts and overlapping flowering patterns with the cowpea crop in most locations have the potential to sustain ample numbers of Bt susceptible Maruca that will mate with possible resistant Maruca and deter resistance development. Further quantitative studies, however, are required from each location to determine if actual Maruca production from alternate hosts is sufficient for a PBR IRM strategy. If verified, this approach would be compatible with the high dose/refuge IRM strategy that includes alternate hosts and non-Bt crops as refuges.
\end{abstract}

Keywords Cowpea $\cdot$ Fabaceae plants $\cdot B t \cdot$ IRM

\section{Introduction}

Cowpea, Vigna unguiculata (L) Walp., is an important food for people and feed for livestock in Sub-Saharan Africa. However, cowpea production has major insect

Prince Christopher Addae paddae@gmail.com

1 African Agricultural Technology Foundation, Abuja, Nigeria

2 CIMMYT, Nairobi, Kenya

3 Institute for Agricultural Research, Zaria, Nigeria

4 CSIR-Savanna Agricultural Research Institute, Tamale, Ghana

5 Institut de L'Environnement et de Recherché Agricoles, Ouagadougou, Burkina Faso

6 Huesing Agricultural and Educational Consulting LLC, Missouri, St. Louis, USA pest constraints especially by Maruca vitrata Fabricius (Lep. Crambidae) (commonly called the legume pod borer or Maruca; latter used hereafter), which can reduce yields 20-80\% (Singh et al. 1990). Controlling Maruca is a challenge for smallholder farmers (Jackai

7 USDA-ARS, Corn Insects and Crop Genetics Research Unit, Ames, IA, USA

8 Department of Entomology, Purdue University, West Lafayette, IN, USA

9 International Institute of Tropical Agriculture, Cotonou, Benin

10 International Crops Research Institute for the Semi-Arid Tropics, Niamey, Niger

11 World Vegetable Centre, Bamako, Mali 
and Adalla 1997). Many growers cannot afford chemical insecticides and when some synthetic insecticides, such as cypermethrin, dimethoate, and endosulfan have been used, Maruca populations have evolved resistance (Bottenberg 1995; Ekesi 1999). Also, many growers lack the proper safety equipment and, because of literacy challenges, do not know how to handle these compounds safely (Onstad et al. 2012; Jepson et al. 2014). Moreover, despite years of research, no cowpea varieties with natural resistance to Maruca have been identified and, when chemical insecticides are used, often 5-8 sprays are required in one cropping season (Fatokun 2002). The chemical insecticide-use challenge and the possibility that Maruca could evolve resistance to available insecticides require other options for pest control in cowpea.

One promising solution to control Maruca is to use genetically engineered (GE) cowpea varieties that provide protection against insects. The lepidopteran specific $c r y l A b$ gene expressed in Pod-Borer Resistant (PBR) cowpea, also known as Bacillus thuringiensis (Bt) cowpea, has demonstrated near-complete control of Maruca in field trials in West Africa (Ba et al. 2019; Addae et al. 2020). Bt cowpea has now been approved by regulators for commercial release in Nigeria (NBMA 2019).

Insect resistance to GE plants in other parts of the world, however, suggests that an insect resistance management (IRM) plan is necessary to protect PBR cowpea from selecting for resistance in Maruca populations (Addae et al. 2020). The African stalk borer, Busseola fusca (Fuller), has evolved resistance to $B t$ maize in South Africa (Van Rensburgh 2007). Also, other moths (Lepidoptera) have evolved resistance to GE crops, for example, the fall armyworm, Spodoptera frugiperda (J.E. Smith), to Bt maize in Puerto Rico, Brazil, and United States (Tabashnik et al. 2009; Storer et al. 2010; Huang et al. 2011). Developing an integrated IRM plan that includes high-dose expression of the trait and use of refuges is recommended as an effective strategy for preventing insect resistance (Carrière et al. 2010; Campagne et al. 2016). The size of the refuge will depend on the distribution of alternate hosts of Maruca in the locations where the PBR cowpea will be grown. Therefore, the objective for this study was to identify the distribution and diversity of alternate hosts in West Africa, specifically Ghana, Nigeria, and Burkina Faso, where cowpea is commonly grown. Determination of alternate hosts will provide essential parameters for developing an IRM strategy that will delay the evolution of resistance to the $B t$ toxin in Maruca populations.

\section{Materials and methods}

Surveys of alternate hosts were conducted in Ghana, Nigeria, and Burkina Faso during October 2014, which is within the cowpea cropping season. There were 25 sites in the Tolon-Kumbungu location in northern Ghana; 25 sites near Bunkure, Kano State and 19 sites near Bomo, Kaduna State in northern Nigeria (44 total sites); 12 sites near Ziniaré, Oubritenga Province in northcentral Burkina Faso and 40 sites near Bobo Dioulasso, Houet Province in southwestern Burkina Faso (52 total sites). The surveys were carried out in three agro-ecological zones, which in some cases overlap: Guinea Savanna (Tolon-Kumbungu and Bomo), Sudan Savanna (Bunkure, Ziniaré, and Bobo Dioulasso), and Sahel Savanna (Ziniaré).

Survey sites were non-systematically selected at each location. Global Positioning System (GPS) coordinates using decimal degrees (DD) were used to identify the location of the alternate hosts. Assessment of alternate hosts within $200 \mathrm{~m}$ of cultivated cowpea farms began by using the transect intercept method of sampling vegetation as described by Greig-Smith (1983). At the beginning of each sampling point, a $200 \mathrm{~m}$ line, referred to as baseline, was established in a designated direction, south-north in this example (Fig. 1). The baseline (200 m) was divided into ten equal parts (marks) starting from 0 to the 10th mark (the end of $200 \mathrm{~m}$ length). Three sets of numbers from the ten designated marks were randomly generated and then allocated to each baseline. Three line transects (transects 1, 2, and 3) of $50 \mathrm{~m}$ each were established starting at the marked points, running perpendicular to the baseline and parallel to one another, in this example a west-east direction. Sampling was done along each transect for terminal shoots, flower buds, flowers, or pods of all Fabaceae plant species. These plants were carefully examined for the presence of Maruca larvae or Maruca-like damage. This procedure was repeated at all the survey points, that is, 25 times in Ghana, 44 in Nigeria, and 52 in Burkina Faso. This resulted in an assessment of alternate hosts in areas within $200 \mathrm{~m}$ of cultivated cowpea that included grazing lands, forests, and other cultivated crops (Fig. 2).

All species belonging to the Fabaceae intercepting the transects were recorded. Crown cover estimates (proportion of the ground cover occupied by a perpendicular projection of the individual plant species) of each plant intercepting the transects were recorded (Greig-Smith 1983). The intercept lengths for each species were summed and each of these values was divided by the total length of the transect. These values then were converted to coverage percentages for each species.

The formula used for calculating plant cover was:

Plant cover $\%=\Sigma \mathrm{i} / \mathrm{Tl} \times 100$

$\Sigma \mathrm{i}=$ sum of individual plant intercept lengths

$\mathrm{Tl}=$ Total length of the transect line 


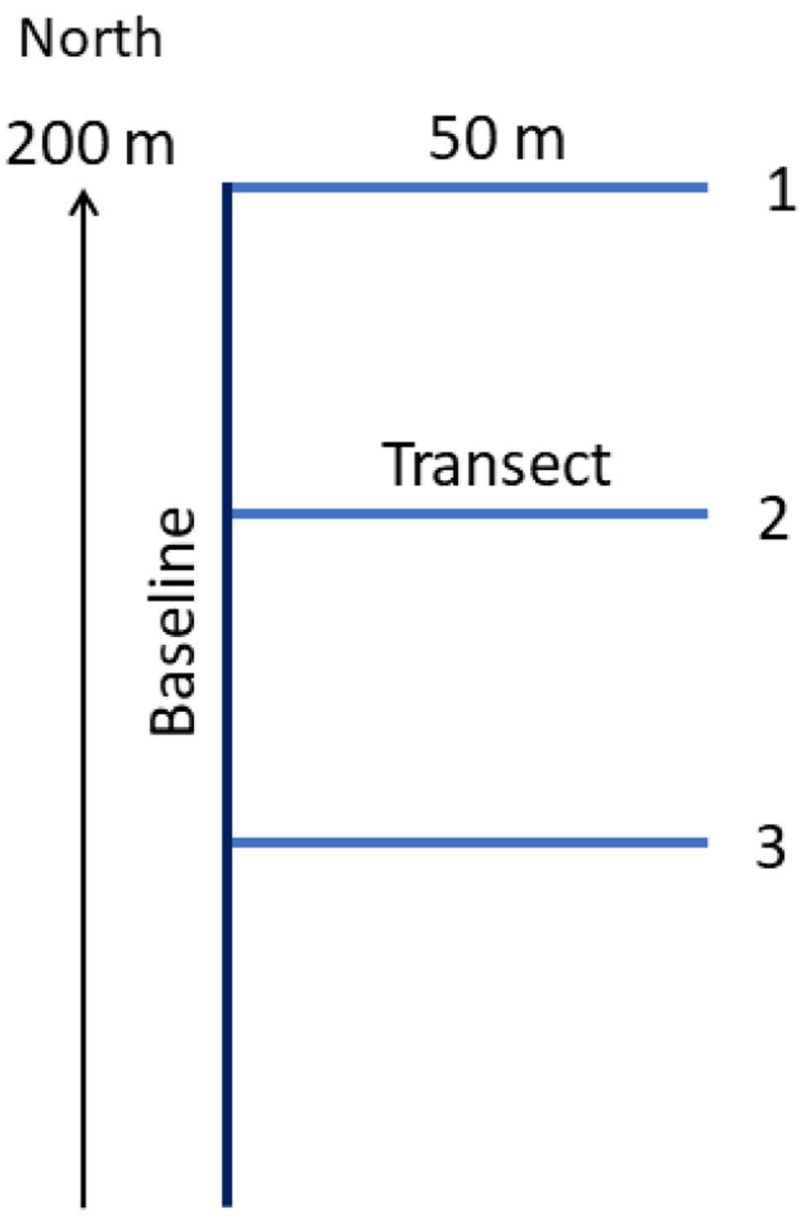

\section{South}

Fig. 1 Three $50 \mathrm{~m}$ transects were established from a $200 \mathrm{~m}$ baseline that extended from a cowpea farm at each survey site

Samples of potential alternate hosts found within $200 \mathrm{~m}$ from the border of cultivated cowpea fields were examined for Maruca damage symptoms on terminal shoots, flower buds, flowers, and pods, which included feeding scars, tunnels, and evidence of frass. Infested plants were dissected for recovery of Maruca larvae. Plants from which the larvae were collected were then identified to species. The larvae were identified by the characteristic translucent, shining body with six rows of black spots running from thorax to abdomen and a dark brown head. The adults were identified by three white patches with black margins on the brown forewings (Sharma et al. 1999). In cases where the infested plants could not be identified readily in the field, voucher specimens were collected, wrapped in tissue paper, placed in plastic bags, and then sent to the authors' respective research institutes for identification. Plants were identified to genera and, if possible, species using the

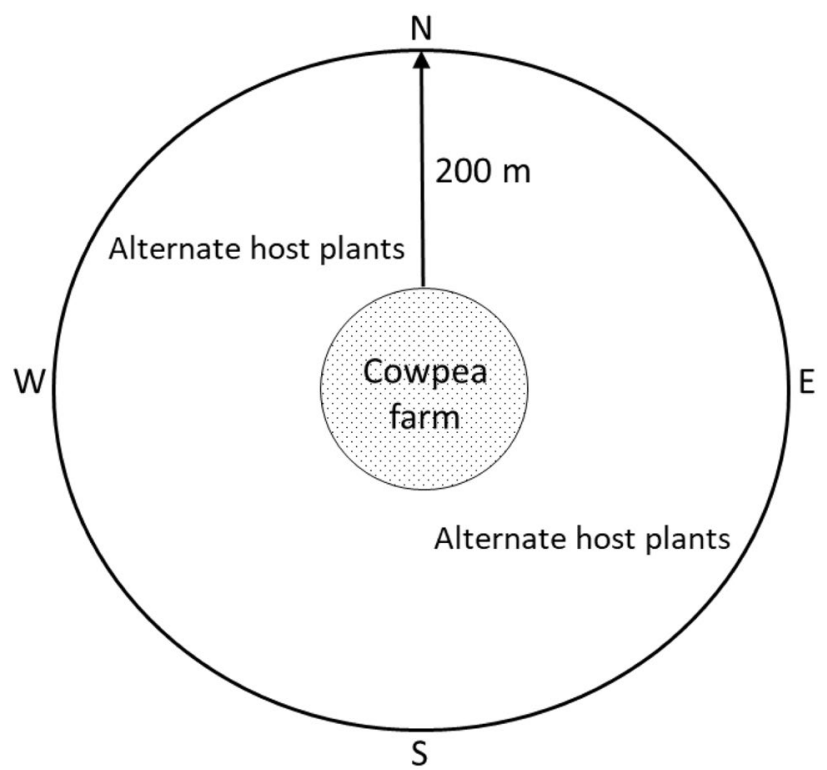

Fig. 2 Diagram of the surveys for alternate host plants within $200 \mathrm{~m}$ of cowpea farms used at each location

following references: Akobundu 1987; Akobundu and Agyakwa 1987. Cowpea field infestations were estimated in Ghana and Nigeria by inspecting 100 randomly distributed cowpea plants for Maruca infestation damage on terminal shoots, flower buds, flowers, and pods. Sampling of Maruca larvae on cowpea farms was timed generally to coincide with flowering. Cowpea plants can compensate for flower removal, so gently removing flowers during sampling reduces plant destruction and limits yield loss (Abudulai and Shepard 2003).

\section{Laboratory rearing and identification of Maruca}

The Maruca larvae collected were sent to the laboratory for rearing and identification. Each specimen was placed in a glass vial containing artificial diet made from a modified Ostrinia nubilalis Hübner diet obtained commercially from Bio-Serv Company, Flemington, NJ. USA (Bio-Serv product No. F9478B-M) without corncob grits but supplemented with cowpea flour. The vials were plugged with cotton wool, labeled, and incubated at $25 \pm 1^{\circ} \mathrm{C}$ and 60-70\% relative humidity (RH) until adult (moths) emergence. Maruca moths were identified by entomologists at each institute. If a Maruca adult was confirmed then the host plant was recorded; otherwise, the plant was not recorded.

\section{Results}

The results for distribution and diversity of alternate hosts of Maruca in five locations within three countries in West Africa are presented in Tables 1-5. The survey found many Fabaceae plant species in areas where cowpea and 


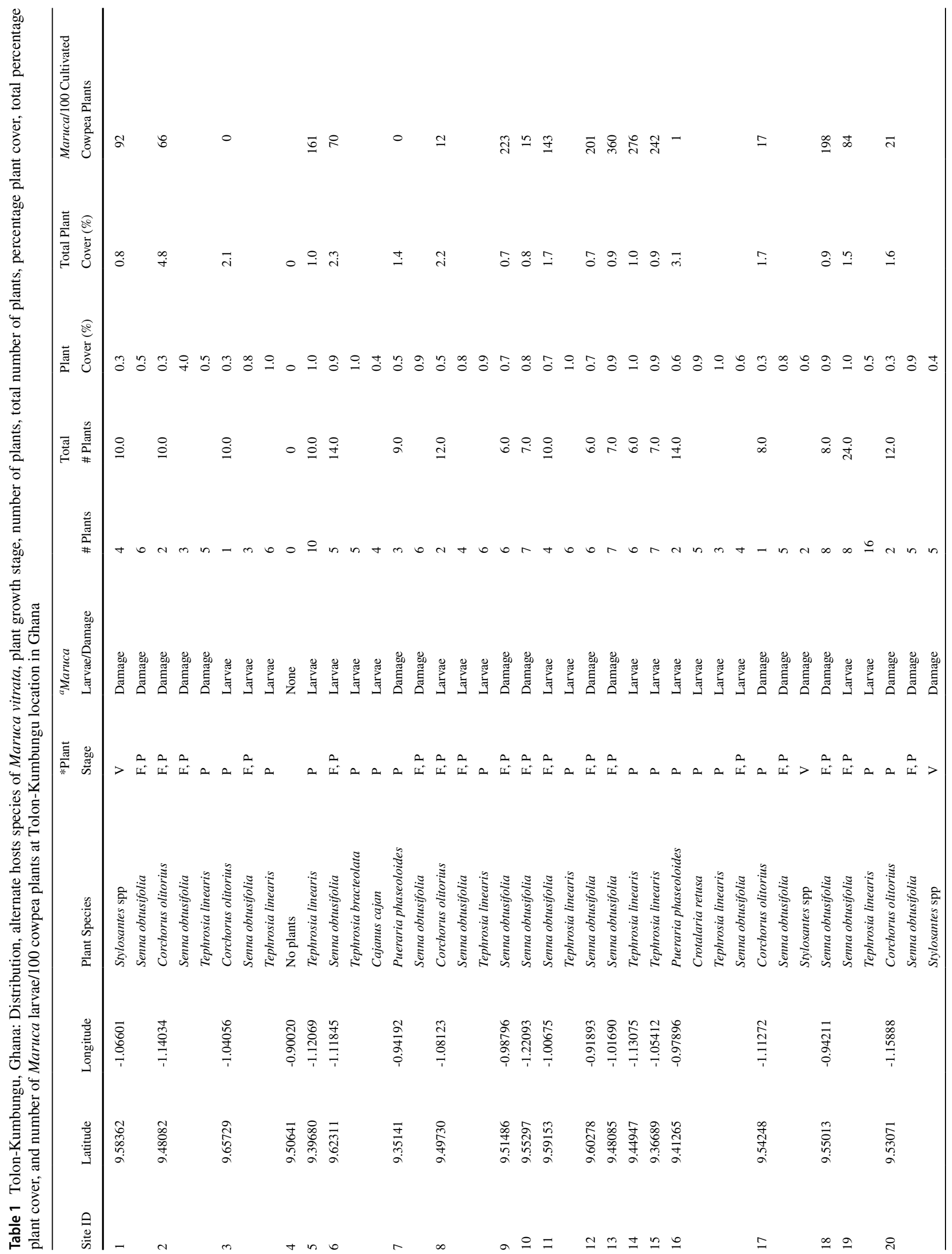




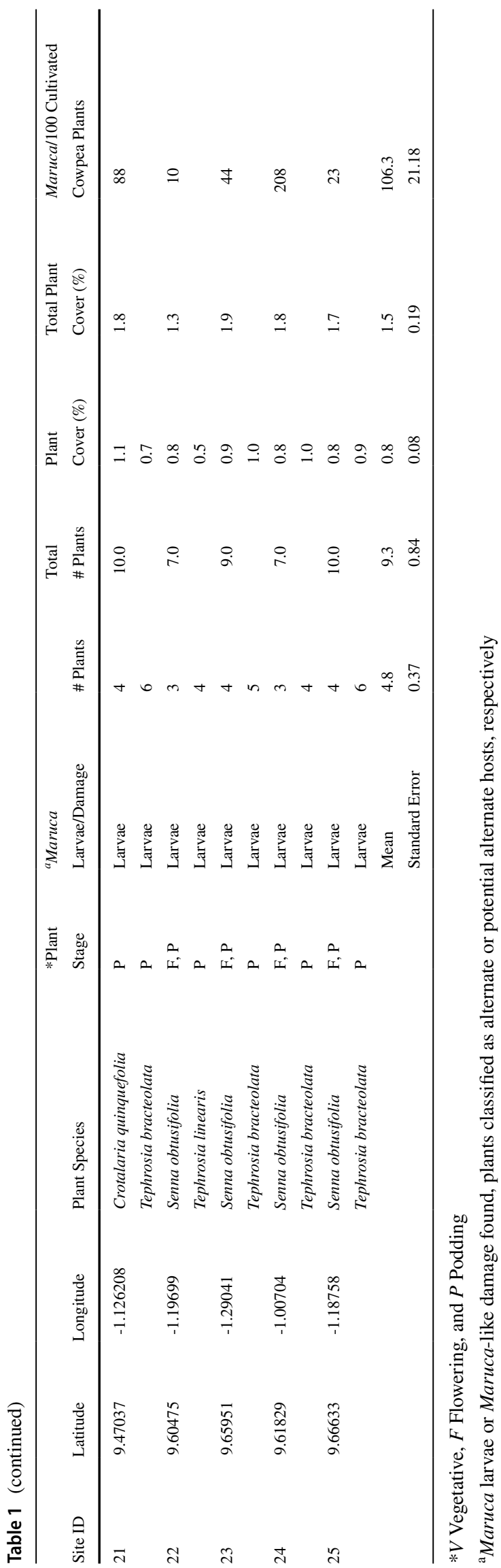

Maruca coexist. The Fabaceae plant species found in the survey areas were classified into three categories based on: 1) presence of Maruca larvae on the plants classified as alternate host, 2) only Maruca-like damage found (potential alternate host), and 3) none, where neither Maruca nor Maruca-like damage, was found. These three categories (larvae, damage, and none) are presented in the Tables 1-5.

At the Tolon-Kumbungu location in Ghana, nine taxa of plants-namely, Senna obtusifolia L., Tephrosia linearis (Willd.) Pers., Tephrosia bracteolata Guill. \& Perr., Corchorus olitorius L., Stylosanthes spp., Pueraria phaseoloides (Roxb.) Benth., Crotalaria quinquefolia L., Cajanus cajan (L.) Millsp., and Crotalaria retusa L. or combinations of them-were found at 24 of the 25 survey sites (Table 1). Most of the plant species were at flowering or podding stages except Stylosanthes spp. that was at the vegetative stage. Besides Stylosanthes spp, all of them had either only Maruca damage symptoms or presence of Maruca larvae. No alternate host plants were found at site 4 . Numbers and mean cover percentages (n, $\overline{\mathrm{x}} \pm \mathrm{SE}$ ) for the four most common plant species found at this location were $S$. obtusifolia $(20,0.96 \pm 0.16), T$. linearis $(9,0.83 \pm 0.08), T$. bracteolate $(5,0.92 \pm 0.06)$, and Corchorus olitorius $(5,0.34 \pm 0.04)$. The average number of potential host plants (larvae, damage, and none) found along the three transects for each site was 9.3 with $1.5 \%$ average plant cover (Table 1). The average number of Maruca larvae on 100 cowpea plants growing in cultivated cowpea fields was 106.3.

Five plant species-namely, Sesbania sesban (L.) Merr., Crotalaria senegalensis (Pers.), Tephrosia bracteolata, Vigna racemosa (G. Don) Hutch. \& Dalziel, T. platycarpa Guill. \& Perr., and combinations of them-were found at 22 of the 25 survey sites at the Bunkure location in Nigeria (Table 2). Only two locations had the latter two species. Most of the plant species were at flowering or podding stages except $C$. senegalensis species that was at vegetative stage. All the plant species found had either presence of Maruca larvae or only damage symptoms. No alternate host plants were found at sites 8,9 and 16. The most common species found at this location were $S$. sesban $(12,1.29 \pm 0.21), C$. senegalensis $(10,1.35 \pm 0.19)$, and $T$. bracteolata $(8,0.81 \pm 0.17)$. The mean number of host plants found along the three transects for each site was 8.4 with $1.5 \%$ average plant cover (Table 2). The average number of Maruca larvae on 100 cowpea plants growing in cultivated cowpea fields was 7.5.

At the Bomo location in Nigeria, four plant speciesnamely, $V$. racemosa, C. senegalensis, Centrosema pubescens Benth., and Sesbania sesban, or combinations of them-were found in 11 of the 19 survey sites (Table 3 ). All the plant species were at flowering or podding 


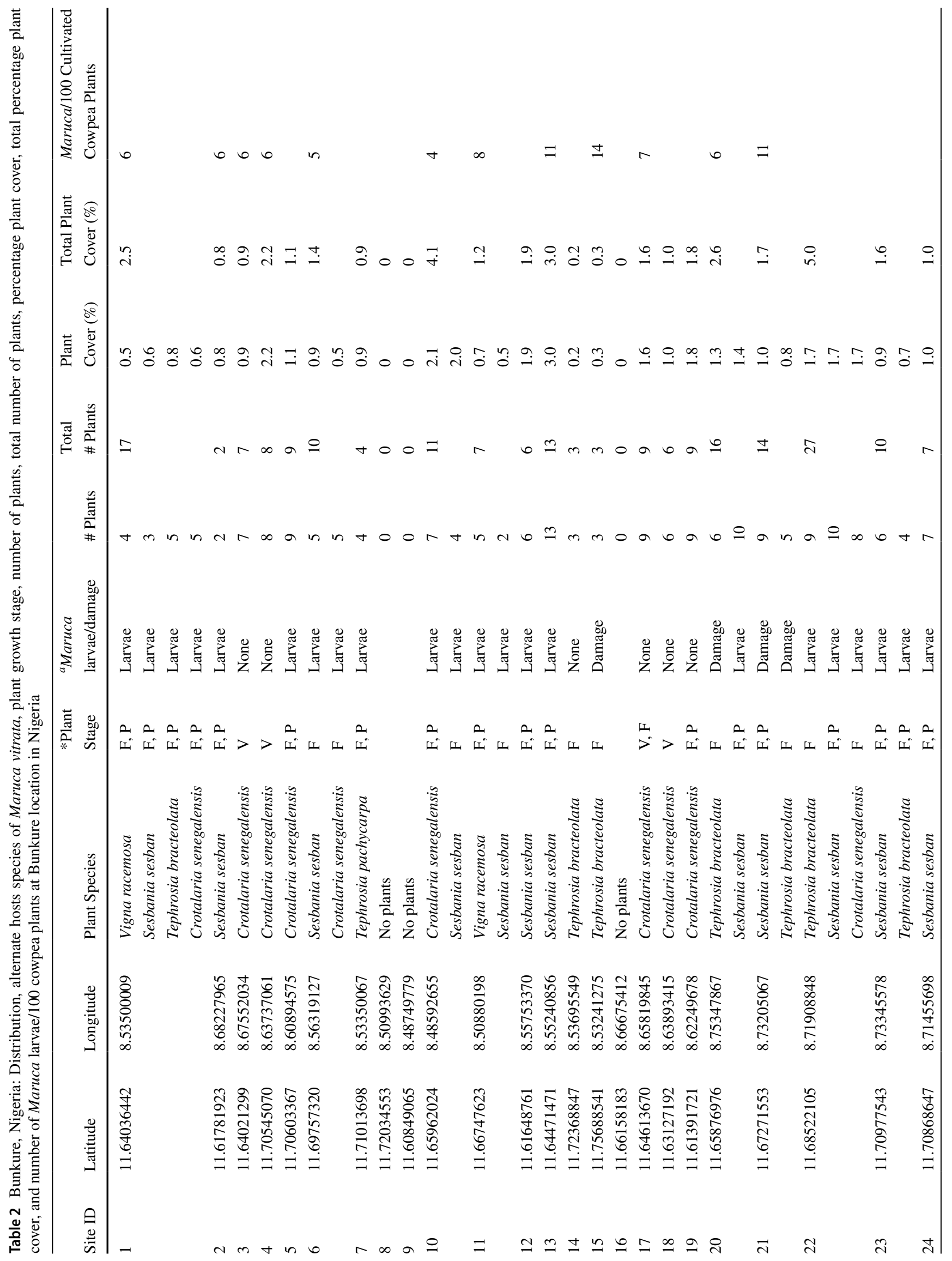


stages except $C$. pubescens that was at the vegetative stage. Also, all the plant species found had either presence of Maruca larvae or only damage symptoms with the exception of two species, $C$. senegalensis, and $C$. pubescens, where neither larvae nor Maruca-like damage were found. No alternate host plants were found at sites $1,4,5,9,10,12$, and 13. The numbers and mean cover percentages for the most common plant species found at this location were $V$. racemosa $(7,0.86 \pm 0.14)$ and Crotalaria senegalensis $(4,0.63 \pm 0.06)$. The mean number of potential host plants found along the three transects for each site was 4.5 with $1.3 \%$ average plant cover (Table 3 ). The average number of Maruca larvae found on 100 cowpea plants growing in cultivated cowpea fields was 5.2.

Three species of alternate hosts-namely, C. retusa, $S$. pachycarpa, and T. bracteolata, all of which had Maruca larvae present-were found at the Ziniaré location in Burkina Faso (Table 4). T. bracteolata was found only in two locations. The other two species either occurred alone or at two locations in combination. Numbers and mean cover percentages for the most common plant species found at this location were $C$. retusa $(8$, $5.1 \pm 2.20)$ and $S$. pachycarpa $(4,3.1 \pm 1.77)$. The mean number of host plants where Maruca was found along the three transects for each site was 5.1 with $7.6 \%$ plant coverage. Most of the plant species were at the flowering stage with a few also at the podding stage. Maruca larvae were not counted in cultivated cowpea fields in Burkina Faso.

At the Bobo Dioulasso location in Burkina Faso, six plant species-namely, Tephrosia nana Kotschy \& Schweinf., Vigna spp., T. bracteolata, C. retusa, S. pachycarpa, and Crotalaria goreensis Guill. \& Perr.-were verified with Maruca larvae present and classified as alternate hosts (Table 5 and 6). Some plant species occurred either singly or in combination in some locations. All plant species were either at flowering/podding stages except $C$. retus $a$ and $C$. goreensis that were only flowering. The mean cover percentages for the most common plant species found at this location are: T. nana $(33,9.4 \pm 1.67)$, Vigna spp., (20, $8.8 \pm 1.55), T$. bracteolate $(12,6.9 \pm 2.10)$, C. retusa $(9$, $5.3 \pm 2.23)$, and $S$. pachycarpa $(7,2.9 \pm 1.04)$. Overall, the average number of host plants where Maruca was found along the three transects for each site was 14.0 with $17.9 \%$ plant coverage. Similarly, the number of Maruca larvae was not counted in cultivated cowpea fields.

\section{Discussion}

Our study aimed to assess the distribution and diversity of alternate host plants for Maruca in selected, important cowpea-growing countries in West Africa. Generally, the alternate host plants including Crotolaria, Sesbania, Tephrosia, and Vigna, species were the most frequently 


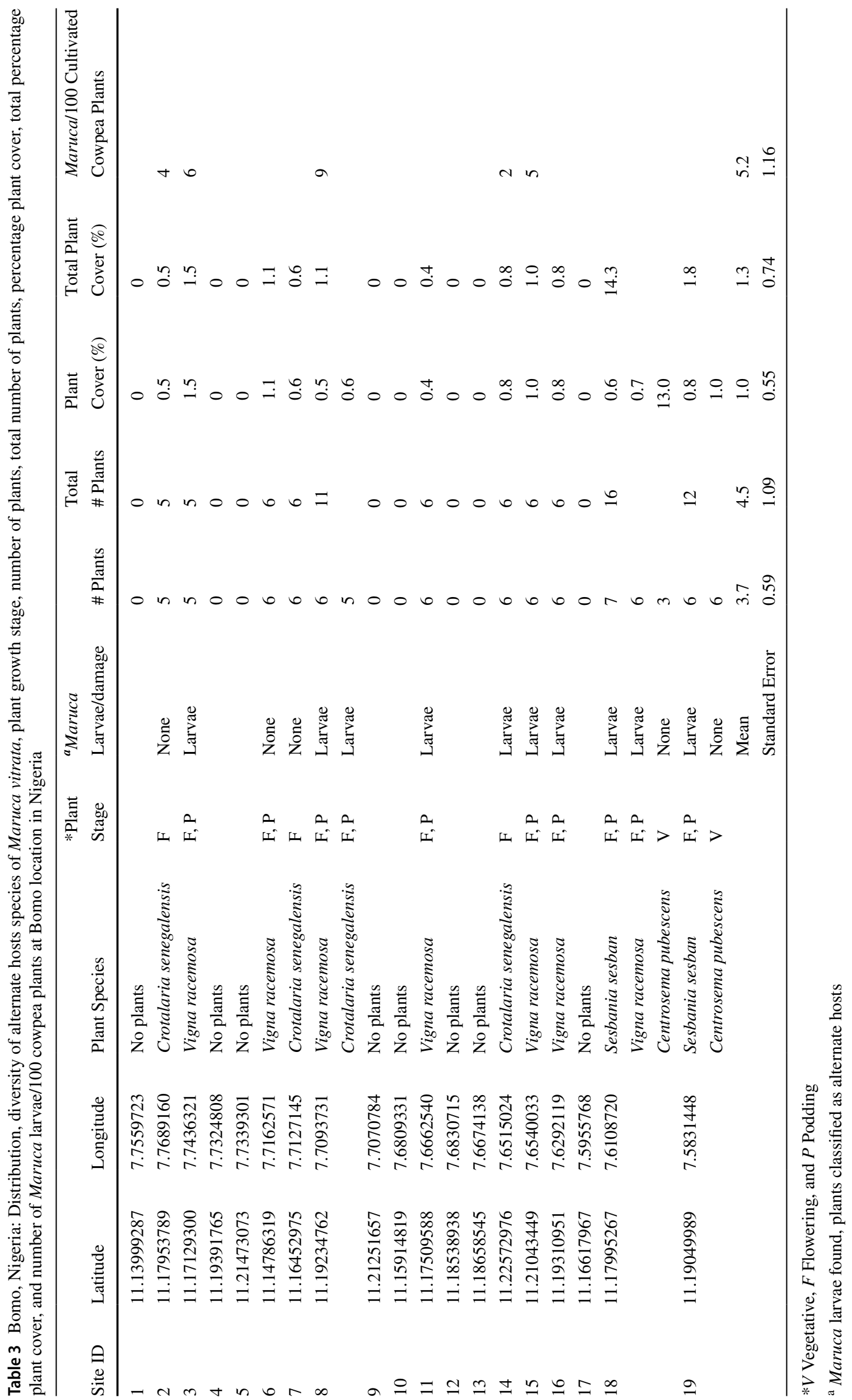


Table 4 Ziniare, Burkina Faso: Distribution, diversity of alternate hosts species of Maruca vitrata, plant growth stage, number of plants, total number of plants, percentage plant cover, and total percentage plant cover at Ziniare location in Burkina Faso

\begin{tabular}{|c|c|c|c|c|c|c|c|c|c|}
\hline Site ID & Latitude & Longitude & Plant Species & $\begin{array}{l}\text { *Plant } \\
\text { Stage }\end{array}$ & $\begin{array}{l}{ }^{a} \text { Maruca } \\
\text { Larvae/Damage }\end{array}$ & \# Plants & $\begin{array}{l}\text { Total } \\
\text { \# Plants }\end{array}$ & $\begin{array}{l}\text { Plant } \\
\text { Cover }(\%)\end{array}$ & $\begin{array}{l}\text { Total Plant } \\
\text { Cover (\%) }\end{array}$ \\
\hline \multirow[t]{2}{*}{1} & \multirow[t]{2}{*}{12.602711} & \multirow[t]{2}{*}{1.440205} & Crotalaria retusa & $\mathrm{F}$ & Larvae & 5 & \multirow[t]{2}{*}{16} & 0.3 & \multirow[t]{2}{*}{0.8} \\
\hline & & & Sesbania pachycarpa & $\mathrm{F}, \mathrm{P}$ & Larvae & 11 & & 0.5 & \\
\hline 2 & 12.538133 & 1.387176 & Crotalaria retusa & $\mathrm{F}$ & Larvae & 2 & 2 & 0.3 & 0.3 \\
\hline 3 & 12.522327 & 1.370214 & Crotalaria retusa & $\mathrm{F}$ & Larvae & 3 & 3 & 15.4 & 15.4 \\
\hline 4 & 12.653579 & 1.320516 & Sesbania pachycarpa & $\mathrm{F}, \mathrm{P}$ & Larvae & 7 & 7 & 4.4 & 4.4 \\
\hline \multirow[t]{2}{*}{5} & \multirow[t]{2}{*}{12.579998} & \multirow[t]{2}{*}{1.333505} & Crotalaria retusa & $\mathrm{F}$ & Larvae & 3 & \multirow[t]{2}{*}{11} & 1.6 & \multirow[t]{2}{*}{1.6} \\
\hline & & & Sesbania pachycarpa & $\mathrm{F}, \mathrm{P}$ & Larvae & 8 & & 0.01 & \\
\hline 6 & 12.582069 & 1.358098 & Crotalaria retusa & $\mathrm{F}$ & Larvae & 4 & 4 & 14.1 & 14.1 \\
\hline 7 & 12.583691 & 1.360641 & Crotalaria retusa & $\mathrm{F}$ & Larvae & 1 & 1 & 3.7 & 3.7 \\
\hline 8 & 12.583260 & 1.375090 & Crotalaria retusa & $\mathrm{F}$ & Larvae & 5 & 5 & 5.2 & 5.2 \\
\hline 9 & 12.583545 & 1.376891 & Sesbania pachycarpa & $\mathrm{F}, \mathrm{P}$ & Larvae & 4 & 4 & 7.5 & 7.5 \\
\hline 10 & 12.583858 & 1.378756 & Tephrosia bracteolata & $\mathrm{F}, \mathrm{P}$ & Larvae & 3 & 3 & 30.1 & 30.1 \\
\hline 11 & 12.583924 & 1.378775 & Crotalaria retusa & $\mathrm{F}$ & Larvae & 1 & 1 & 0.3 & 0.3 \\
\hline \multirow[t]{3}{*}{12} & \multirow[t]{3}{*}{12.583216} & \multirow[t]{3}{*}{1.378859} & \multirow[t]{3}{*}{ Tephrosia bracteolata } & \multirow[t]{3}{*}{ F, P } & Larvae & 4 & 4 & 8.2 & 8.2 \\
\hline & & & & & Mean & 4.4 & 5.1 & 6.5 & 7.6 \\
\hline & & & & & Standard Error & 0.74 & 1.27 & 2.26 & 2.51 \\
\hline
\end{tabular}

*F Flowering and $P$ Podding

${ }^{\text {a }}$ Maruca larvae found, plants classified as alternate hosts

encountered among sites and locations. Crotalaria species were commonly found in all the five survey locations in Ghana, Nigeria, and Burkina Faso. Tephrosia species were found mostly at Tolon-Kumbungu (Ghana), Bunkure (Nigeria), and Bobo Dioulasso (Burkina Faso). Sesbania species were found at Bomo (Nigeria) and the two locations in Burkina Faso. Vigna species were found at both Bunkure and Bomo (Nigeria), and Bobo Dioulasso (Burkina Faso). Senna obtusifolia was especially prominent in Tolon-Kumbungu (Ghana). Previous studies have identified most of these species as alternate hosts of Maruca (Tamò et al. 2002; Arodokoun et al. 2003), corroborating our findings. There were instances where only damage symptoms were observed on the plants and those plants were classified as potential alternate hosts of Maruca. Also, there were plants where neither Maruca larvae nor Maruca-like damage were found. This occurred especially at the Bomo (Nigeria) location. These same plant species, however, except for Centrosema pubescens, had Maruca larvae or damage at other locations. There were sites where no plant species were found because of scarce vegetation or poor accessibility, especially at Bomo. Unlike the higher numbers of Maruca larvae found on the cowpea plants in Ghana, few Maruca larvae were found on cowpea plants in Nigeria because the growers had sprayed their crops with chemical insecticides prior to conducting the survey or the pest pressure was low that year. Another challenge was sorting through the many plant species that were encountered during the surveys. Future studies could address this by focusing on the major known alternate species at a location.

The extensive distribution and diversity of the alternate plant species within the surveyed locations indicate that they could be used as refuges when $B t$ cowpea is introduced. Many Maruca larvae were found on both cowpea plants on the farms and alternate hosts growing within $200 \mathrm{~m}$ of the farms in Tolon-Kumbungu (Ghana), and Bunkure (Nigeria) locations. While the presence of Maruca larvae on cowpea plants was not determined in Burkina Faso, earlier studies by Traore et al. (2014) reported that Maruca populations overlapped on cultivated cowpea and alternate hosts plants during the rainy season in southwestern Burkina Faso. These observations suggest that adult Maruca emerging from cultivated cowpea and alternate host plants in close vicinity are very likely to mix and mate. Small farms embedded in areas with alternate hosts particularly could benefit. For example, a one-hectare farm $\left(10,000 \mathrm{~m}^{2}\right)$ potentially could attract Maruca from a radius of $200 \mathrm{~m}$ (or more). In this case, Maruca would be attracted from a minimum area of $125,600 \mathrm{~m}^{2}$, which is more than 12 times the size of the farm. Likewise, half, quarter, and one-tenth hectare farms would attract Maruca from proportionally larger areas, that is, more than 25, 50, and 125 times larger, respectively. Consequently, when $B t$ cowpea is planted in similar environments, resistant moths could mate with susceptible moths, which lowers the frequency of the resistance alleles 
Table 5 Distribution, diversity of alternate hosts species of Maruca vitrata, plant growth stage, number of plants, and percentage plant cover at Bobo Dioulasso location in Burkina Faso (Part 1)

\begin{tabular}{|c|c|c|c|c|c|c|c|c|c|}
\hline Site ID & Latitude & Longitude & Plant Species & $\begin{array}{l}\text { Plant } \\
\text { Stage }\end{array}$ & $\begin{array}{l}{ }^{\mathrm{a}} \text { Maruca } \\
\text { Larvae/Damage }\end{array}$ & \# Plants & $\begin{array}{l}\text { Total } \\
\text { \# Plants }\end{array}$ & $\begin{array}{l}\text { Plant } \\
\text { Cover }(\%)\end{array}$ & $\begin{array}{l}\text { Total Plant } \\
\text { Cover }(\%)\end{array}$ \\
\hline 1 & 11.363926 & -4.357493 & Crotalaria retusa & $\mathrm{F}$ & Larvae & 10 & 10 & 21.6 & 21.6 \\
\hline \multirow[t]{2}{*}{2} & \multirow[t]{2}{*}{11.401730} & \multirow[t]{2}{*}{-4.059483} & Vigna spp. & $\mathrm{F}, \mathrm{P}$ & Larvae & 7 & \multirow[t]{2}{*}{12} & 22.7 & \multirow[t]{2}{*}{30.9} \\
\hline & & & Vigna spp. & $\mathrm{F}, \mathrm{P}$ & Larvae & 5 & & 8.2 & \\
\hline 3 & 11.523662 & -3.988279 & Tephrosia nana & $\mathrm{F}, \mathrm{P}$ & Larvae & 21 & 28 & 15.8 & 17.2 \\
\hline 4 & 11.495369 & -4.007024 & Sesbania pachycarpa & $\mathrm{F}, \mathrm{P}$ & Larvae & 7 & & 1.4 & \\
\hline \multirow[t]{2}{*}{5} & \multirow[t]{2}{*}{11.383900} & \multirow[t]{2}{*}{-4.078004} & Tephrosia nana & $\mathrm{F}, \mathrm{P}$ & Larvae & 8 & \multirow[t]{2}{*}{23} & 3.2 & \multirow[t]{2}{*}{3.3} \\
\hline & & & Tephrosia nana & $\mathrm{F}, \mathrm{P}$ & Larvae & 15 & & 0.1 & \\
\hline \multirow[t]{2}{*}{6} & \multirow[t]{2}{*}{11.351522} & \multirow[t]{2}{*}{-4.120257} & Sesbania pachycarpa & $\mathrm{F}, \mathrm{P}$ & Larvae & 5 & \multirow[t]{2}{*}{14} & 5.3 & \multirow[t]{2}{*}{5.5} \\
\hline & & & Tephrosia bracteolata & $\mathrm{F}, \mathrm{P}$ & Larvae & 9 & & 0.2 & \\
\hline \multirow[t]{3}{*}{7} & \multirow[t]{3}{*}{11.294763} & \multirow[t]{3}{*}{-4.201514} & Tephrosia nana & $\mathrm{F}, \mathrm{P}$ & Larvae & 11 & \multirow[t]{3}{*}{24} & 30.2 & \multirow[t]{3}{*}{75.7} \\
\hline & & & Tephrosia nana & $\mathrm{F}, \mathrm{P}$ & Larvae & 6 & & 15.4 & \\
\hline & & & Tephrosia nana & $\mathrm{F}, \mathrm{P}$ & Larvae & 7 & & 30.1 & \\
\hline \multirow[t]{2}{*}{8} & \multirow[t]{2}{*}{11.193713} & -3.981966 & Tephrosia nana & $\mathrm{F}, \mathrm{P}$ & Larvae & 10 & 13 & 0.7 & 4.6 \\
\hline & & & Crotalaria retusa & $\mathrm{F}$ & Larvae & 3 & & 3.9 & \\
\hline 9 & 10.847111 & -4.610803 & Crotalaria goreensis & $\mathrm{F}$ & Larvae & 2 & 8 & 0.003 & 1.0 \\
\hline & & & Tephrosia nana & $\mathrm{F}, \mathrm{P}$ & Larvae & 6 & & 1.0 & \\
\hline 10 & 10.756940 & -4.718950 & Sesbania pachycarpa & $\mathrm{F}, \mathrm{P}$ & Larvae & 5 & 16 & 7.7 & 15.1 \\
\hline & & & Tephrosia nana & $\mathrm{F}$ & Larvae & 11 & & 7.4 & \\
\hline 11 & 10.784480 & -4.695112 & Tephrosia nana & $\mathrm{F}, \mathrm{P}$ & Larvae & 17 & 22 & 3.9 & 11.5 \\
\hline & & & Tephrosia bracteolata & $\mathrm{F}, \mathrm{P}$ & Larvae & 5 & & 7.6 & \\
\hline 12 & 10.783881 & -4.694111 & Vigna spp. & $\mathrm{F}, \mathrm{P}$ & Larvae & 1 & 29 & 15.5 & 52.3 \\
\hline 13 & 10.851357 & -4.608559 & Crotalaria goreensis & $\mathrm{F}$ & Larvae & 6 & & 15.5 & \\
\hline & & & Tephrosia nana & $\mathrm{F}, \mathrm{P}$ & Larvae & 9 & & 1.0 & \\
\hline & & & Crotalaria retusa & $\mathrm{F}$ & Larvae & 4 & & 6.1 & \\
\hline & & & Tephrosia bracteolata & $\mathrm{F}, \mathrm{P}$ & Larvae & 6 & & 0.001 & \\
\hline & & & Vigna spp. & $\mathrm{F}, \mathrm{P}$ & Larvae & 3 & & 14.2 & \\
\hline 14 & 10.960695 & -4.449583 & Vigna spp. & $\mathrm{F}, \mathrm{P}$ & Larvae & 6 & 17 & 0.003 & 14.5 \\
\hline & & & Tephrosia bracteolata & $\mathrm{F}, \mathrm{P}$ & Larvae & 5 & & 3.0 & \\
\hline & & & Tephrosia nana & $\mathrm{F}, \mathrm{P}$ & Larvae & 6 & & 11.5 & \\
\hline 15 & 11.013442 & -4.397813 & Vigna spp. & $\mathrm{F}, \mathrm{P}$ & Larvae & 5 & 24 & 0.003 & 32.6 \\
\hline & & & Tephrosia nana & $\mathrm{F}, \mathrm{P}$ & Larvae & 10 & & 11.5 & \\
\hline & & & Vigna spp. & $\mathrm{F}, \mathrm{P}$ & Larvae & 3 & & 15.6 & \\
\hline & & & Crotalaria goreensis & $\mathrm{F}$ & Larvae & 6 & & 5.5 & \\
\hline 16 & 11.097236 & -4.315528 & Crotalaria goreensis & $\mathrm{F}$ & Larvae & 5 & 8 & 21.6 & 40.3 \\
\hline & & & Tephrosia nana & $\mathrm{F}, \mathrm{P}$ & Larvae & 3 & & 18.7 & \\
\hline 17 & 11.096933 & -4.614221 & Vigna spp. & $\mathrm{F}, \mathrm{P}$ & Larvae & 4 & 13 & 3.5 & 4.2 \\
\hline & & & Tephrosia nana & $\mathrm{F}, \mathrm{P}$ & Larvae & 9 & & 0.7 & \\
\hline 18 & 11.068907 & -4.772015 & Tephrosia bracteolata & $\mathrm{F}, \mathrm{P}$ & Larvae & 6 & 15 & 3.2 & 23.7 \\
\hline & & & Vigna spp. & $\mathrm{F}, \mathrm{P}$ & Larvae & 5 & & 0.9 & \\
\hline & & & Tephrosia bracteolata & $\mathrm{F}, \mathrm{P}$ & Larvae & 4 & & 19.6 & \\
\hline 19 & 10.985292 & -4.837563 & Sesbania pachycarpa & $\mathrm{F}, \mathrm{P}$ & Larvae & 8 & 29 & 2.8 & 6.6 \\
\hline & & & Tephrosia bracteolata & $\mathrm{F}, \mathrm{P}$ & Larvae & 11 & & 0.003 & \\
\hline & & & Tephrosia bracteolata & $\mathrm{F}, \mathrm{P}$ & Larvae & 10 & & 3.8 & \\
\hline 20 & 10.978962 & -4.848805 & Vigna spp. & $\mathrm{F}, \mathrm{P}$ & Larvae & 6 & 6 & 3.0 & 3.0 \\
\hline
\end{tabular}

* F Flowering and $P$ Podding

${ }^{\text {a } M a r u c a}$ larvae found, plants classified as alternate hosts 
Table 6 Distribution, diversity of alternate hosts species of Maruca vitrata, plant growth stage, number of plants, and percentage plant cover at Bobo Dioulasso location in Burkina Faso (Part 2 with means)

\begin{tabular}{|c|c|c|c|c|c|c|c|c|c|}
\hline Site ID & Latitude & Longitude & Plant Species & $\begin{array}{l}\text { Plant } \\
\text { Stage }\end{array}$ & $\begin{array}{l}{ }^{\mathrm{a}} \text { Maruca } \\
\text { Larvae/Damage }\end{array}$ & \# Plants & $\begin{array}{l}\text { Total } \\
\text { \# Plants }\end{array}$ & $\begin{array}{l}\text { Plant } \\
\text { Cover }(\%)\end{array}$ & $\begin{array}{l}\text { Total Plant } \\
\text { Cover }(\%)\end{array}$ \\
\hline \multirow[t]{2}{*}{21} & \multirow[t]{2}{*}{11.083893} & \multirow[t]{2}{*}{-4.663021} & Tephrosia bracteolata & $\mathrm{F}, \mathrm{P}$ & Larvae & 5 & \multirow[t]{2}{*}{12} & 4.2 & \multirow[t]{2}{*}{23.6} \\
\hline & & & Vigna spp. & $\mathrm{F}, \mathrm{P}$ & Larvae & 7 & & 19.4 & \\
\hline \multirow[t]{5}{*}{22} & \multirow[t]{5}{*}{11.121591} & \multirow[t]{5}{*}{-4.492918} & Tephrosia nana & $\mathrm{F}, \mathrm{P}$ & Larvae & 4 & \multirow[t]{5}{*}{34} & 0.8 & \multirow[t]{5}{*}{33.0} \\
\hline & & & Crotalaria retusa & $\mathrm{F}$ & Larvae & 10 & & 7.5 & \\
\hline & & & Vigna spp. & $\mathrm{F}, \mathrm{P}$ & Larvae & 2 & & 13.2 & \\
\hline & & & Crotalaria retusa & $\mathrm{F}$ & Larvae & 9 & & 0.005 & \\
\hline & & & Tephrosia nana & $\mathrm{F}, \mathrm{P}$ & Larvae & 9 & & 11.5 & \\
\hline 23 & 11.203598 & -4.398504 & Tephrosia nana & $\mathrm{F}, \mathrm{P}$ & Larvae & 14 & 14 & 31.1 & 31.1 \\
\hline 24 & 11.417590 & -4.436721 & Tephrosia nana & $\mathrm{F}, \mathrm{P}$ & Larvae & 5 & 5 & 30.1 & 30.1 \\
\hline \multirow[t]{2}{*}{25} & \multirow[t]{2}{*}{11.618431} & \multirow[t]{2}{*}{-4.577209} & Sesbania pachycarpa & $\mathrm{F}, \mathrm{P}$ & Larvae & 2 & \multirow[t]{2}{*}{6} & 2.5 & \multirow[t]{2}{*}{4.5} \\
\hline & & & Crotalaria retusa & $\mathrm{F}, \mathrm{P}$ & Larvae & 4 & & 2.0 & \\
\hline 26 & 11.620683 & -4.564374 & Tephrosia nana & $\mathrm{F}, \mathrm{P}$ & Larvae & 8 & 8 & 10.2 & 10.2 \\
\hline \multirow[t]{2}{*}{27} & \multirow[t]{2}{*}{11.691362} & \multirow[t]{2}{*}{-4.527594} & Tephrosia nana & $\mathrm{F}$ & Larvae & 1 & \multirow[t]{2}{*}{4} & 6.8 & \multirow[t]{2}{*}{10.9} \\
\hline & & & Tephrosia nana & $\mathrm{F}, \mathrm{P}$ & Larvae & 3 & & 4.1 & \\
\hline 28 & 11.690357 & -4.526324 & Sesbania pachycarpa & $\mathrm{F}, \mathrm{P}$ & Larvae & 4 & 4 & 0.006 & 0.006 \\
\hline \multirow[t]{4}{*}{29} & \multirow[t]{4}{*}{11.780450} & -4.516463 & Tephrosia nana & $\mathrm{F}, \mathrm{P}$ & Larvae & 8 & 20 & 1.1 & 30 \\
\hline & & & Tephrosia nana & $\mathrm{F}, \mathrm{P}$ & Larvae & 1 & & 14.3 & \\
\hline & & & Tephrosia nana & $\mathrm{F}$ & Larvae & 6 & & 13.8 & \\
\hline & & & Crotalaria retusa & $\mathrm{F}$ & Larvae & 5 & & 0.8 & \\
\hline 30 & 11.512473 & -4.490122 & Sesbania pachycarpa & $\mathrm{F}, \mathrm{P}$ & Larvae & 10 & 10 & 0.5 & 0.5 \\
\hline 31 & 11.513628 & -4.490196 & Crotalaria retusa & $\mathrm{F}$ & Larvae & 8 & 13 & 0.3 & 3.3 \\
\hline & & & Vigna spp. & $\mathrm{F}, \mathrm{P}$ & Larvae & 5 & & 3.0 & \\
\hline 32 & 11.192714 & -3.896319 & Vigna spp. & $\mathrm{F}, \mathrm{P}$ & Larvae & 5 & 5 & 4.2 & 4.2 \\
\hline 33 & 11.192781 & -3.896094 & Vigna spp. & $\mathrm{F}, \mathrm{P}$ & Larvae & 4 & 11 & 14.2 & 24.5 \\
\hline & & & Tephrosia bracteolata & $\mathrm{F}, \mathrm{P}$ & Larvae & 7 & & 10.3 & \\
\hline 34 & 11.193407 & -3.896113 & Vigna spp. & $\mathrm{F}, \mathrm{P}$ & Larvae & 5 & 5 & 3.5 & 3.5 \\
\hline 35 & 11.205040 & -3.822919 & Vigna spp. & $\mathrm{F}, \mathrm{P}$ & Larvae & 3 & 4 & 3.2 & 4.0 \\
\hline & & & Tephrosia nana & $\mathrm{F}, \mathrm{P}$ & Larvae & 1 & & 0.8 & \\
\hline 36 & 11.202236 & -3.793131 & Tephrosia nana & $\mathrm{F}, \mathrm{P}$ & Larvae & 5 & 11 & 1.0 & 9.5 \\
\hline & & & Tephrosia nana & $\mathrm{F}, \mathrm{P}$ & Larvae & 1 & & 0.002 & \\
\hline & & & Tephrosia nana & $\mathrm{F}, \mathrm{P}$ & Larvae & 5 & & 8.5 & \\
\hline 37 & 11.222421 & -3.726286 & Tephrosia nana & $\mathrm{F}, \mathrm{P}$ & Larvae & 3 & 12 & 1.2 & 20.4 \\
\hline & & & Crotalaria retusa & $\mathrm{F}$ & Larvae & 2 & & 5.5 & \\
\hline & & & Tephrosia nana & $\mathrm{F}, \mathrm{P}$ & Larvae & 6 & & 8.3 & \\
\hline & & & Vigna spp. & $\mathrm{F}, \mathrm{P}$ & Larvae & 1 & & 5.4 & \\
\hline 38 & 11.230347 & -3.716379 & Tephrosia nana & $\mathrm{F}, \mathrm{P}$ & Larvae & 16 & 16 & 10.2 & 10.2 \\
\hline 39 & 11.193137 & -3.998305 & Vigna spp. & $\mathrm{F}, \mathrm{P}$ & Larvae & 2 & 18 & 12.7 & 40.9 \\
\hline & & & Tephrosia nana & $\mathrm{F}, \mathrm{P}$ & Larvae & 5 & & 5.1 & \\
\hline & & & Vigna spp. & $\mathrm{F}, \mathrm{P}$ & Larvae & 2 & & 13.6 & \\
\hline & & & Tephrosia bracteolata & $\mathrm{F}, \mathrm{P}$ & Larvae & 9 & & 9.5 & \\
\hline 40 & 11.221571 & -4.472499 & Tephrosia bracteolata & $\mathrm{F}, \mathrm{P}$ & Larvae & 10 & 10 & 21.6 & 21.6 \\
\hline & & & & & Mean & 6.3 & 14.0 & 8.0 & 17.9 \\
\hline & & & & & Standard Error & 0.41 & 1.28 & 0.88 & 2.67 \\
\hline
\end{tabular}

* $F$ Flowering and $P$ Podding

${ }^{\text {a }}$ Maruca larvae found, plants classified as alternate hosts 
(Roush 1997; Gould 1998). This random mating of moths will help delay and perhaps prevent Maruca from developing resistance to the $B t$ toxin.

In this study, many Maruca larvae were found on alternate hosts during the rainy season. Traore et al. (2014) reported that during the dry season, Maruca maintained a permanent population on the wild host plants Mucuna poggei Taub. and Daniella oliveri Rolfe in Burkina Faso. Arodokoun et al. (2003) also found Maruca in the dry season in southern and central Benin. There is evidence that Maruca moths migrate to the north during the rainy season and disperse from local wild hosts (Bottenberg et al. 1997; Ba et al. 2009; Margam et al. 2010).

Utilization of wild hosts plants can be an effective component of IRM strategies for transgenic crops (Jackson et al. 2008). Establishing refuges, however, will be required at some locations where alternate hosts plants are not found or production is low. In fact, Margam et al. (2010) after surveying a total of 67 sites in proximity to cowpea fields in the Sudan Savannah (Kano, Nigeria), the Northern Guinea Savannah (Zaria, Nigeria), and the Sahel Savannah (Maradi, Niger) ecological zones, indicated that alternate host plants for Maruca are scarce or absent during the cowpea-growing season in these areas. Their findings were inconsistent with earlier studies that showed an abundance of alternate hosts in West Africa (Atachi and Djihou 1994; Tamò et al. 2002; Arodokoun et al. 2003). They hypothesized that the lack of alternate hosts in their survey was likely due to the northerly arid region of the survey. They concluded that since Maruca is migratory into those northerly arid regions and becomes locally extinct at the end of each growing season, the lack of alternate hosts would not impact IRM strategies (Margam et al. 2010). While our study had some geographical overlap with the Margam et al. (2010) study, our survey areas were focused more in the semi-arid cowpea zones where more alternate hosts would be expected (Ba et al. 2019). It is noteworthy that our study was qualitative and only identified the potential for Maruca production. Further quantitative studies are needed to determine Maruca population sizes that originate from alternate hosts relative to those that originate from cultivated cowpea in order to model their potential for use in an IRM plan.

Another way to increase the number of Maruca that originate from alternate hosts includes the use of a cultivated crop, e.g., pigeon pea, Cajanus cajan. This crop is an alternate host for Maruca in Ghana and could be planted as a refuge as well as food for the growers. The refuge can be comprised of cultivated non-transgenic crop plants or perhaps any other host plants that can support significant population sizes for the targeted insect pest species (Agunbiade et al. 2014). Vacher et al. (2003) suggested refuge fractions of less than $25 \%$ will minimize pest density while efficiently delaying resistance. Further studies should be done to ascertain the appropriate refuge percentage required for $B t$ cowpea to ensure effective insect resistance management. The high dose/refuge strategy is considered central to managing resistance to $B t$ toxins (Carrière et al. 2010; Campagne et al. 2016). Pod-borer Resistant cowpea has near complete control of Maruca in field tests in West Africa (Addae et al. 2020). Breeding is currently in progress to introduce a second $B t$ gene in addition to the $c r y l A b$ gene at research institutes in West Africa (Bett et al. 2017). Two or more genes in a crop has been reported to delay development of resistance to $B t$ toxins better than a single gene. The second gene, however, does not need to be high dose (Head and Greenplate 2012; Onstad et al. 2012). Other information required for fine-tuning an IRM strategy should include a better understanding of pest biology/ecology including interactions with biocontrol agents, product deployment patterns, local cropping systems, and plans for insect susceptibility monitoring, grower communications on compliance, and remedial action should resistance occur.

\section{Conclusion}

There are abundant and diverse alternate hosts for Maruca in the surveyed locations where cowpea is grown in Ghana, Nigeria, and Burkina Faso. The alternate hosts with their flowering and podding patterns may be adequate for most of the sites in each location to serve as a refuge to delay Maruca from developing resistance to the $B t$ toxin until a $B t$ cowpea variety with two insecticidal genes is deployed. This qualitative study suggests there is potential for adequate refuge from alternate hosts, but follow-up quantitative studies are necessary to verify this. Refuges should be established where alternate hosts are not available or uncertain. A robust IRM strategy is required for growing Pod-borer Resistant $B t$ cowpea. This strategy should include abundant alternate hosts for Maruca. However, in areas where alternate hosts are limited or missing, growers' compliance to produce non$B t$ cowpea will be needed. Future studies could determine better estimates of the population size of Maruca in the refuge as compared to those of $B t$ cowpea. Such insights would allow effective modeling to understand the longterm potential for the evolution of resistance in Maruca populations in $B t$ cowpea.

Acknowledgements The authors are thankful to the United States Agency For International Development (USAID; AID-OAAA-14-00035), the African Agricultural Technology Foundation (AATF), the Institute of Agricultural Research (IAR) in Nigeria, Institut de l'Environnement et de Recherché Agricoles (INERA) in Burkina Faso, and the Savana Agricultural Research Institute (SARI) in Ghana for providing funds and support for the Podborer Resistant Cowpea 
project. We are grateful to Hamza Adamu of IAR, Herve Bama at INERA and Ahmed Seidu at SARI for their field technical assistance.

\section{Declarations}

Conflict of interest The authors declare that they have no conflict of interests.

Open Access This article is licensed under a Creative Commons Attribution 4.0 International License, which permits use, sharing, adaptation, distribution and reproduction in any medium or format, as long as you give appropriate credit to the original author(s) and the source, provide a link to the Creative Commons licence, and indicate if changes were made. The images or other third party material in this article are included in the article's Creative Commons licence, unless indicated otherwise in a credit line to the material. If material is not included in the article's Creative Commons licence and your intended use is not permitted by statutory regulation or exceeds the permitted use, you will need to obtain permission directly from the copyright holder. To view a copy of this licence, visit http://creativecommons.org/licenses/by/4.0/.

\section{References}

Abudulai M, Shepard BM (2003) Cowpea damage simulation to determine critical reproductive growth stages. J Agric Urban Entomol 20:25-29. http://scentsoc.org/Volumes/JAUE/v20/25.pdf

Addae PC, Ishiyaku MF, Tignegre JB, Ba NM, Bationo JB, Atokple IDK, Abudulai M, Dabiré-Binso CL, Traore F, Saba M, Umar ML, Adazebra GA, Onyekachi FN, Nemeth MA, Huesing JE, Beach LR, Higgins TJV, Hellmich RL, Pittendrigh BR (2020) Efficacy of a crylAb gene for control of Maruca vitrata (Lepidoptera: Crambidae) in cowpea (Fabales: Fabaceae). J Econ Ent 113:974-979. https://doi.org/10.1093/jee/toz367

Agunbiade TA, Coates BS, Datinon B, Djouaka R, Sun W, Tamò M, Pittendrigh BR (2014) Genetic differentiation among Maruca vitrata F. (Lepidoptera: Crambidae) populations on cultivated cowpea and wild host plants: implications for insect resistance management and biological control strategies. PLoS One. https://doi.org/10.1371/journal.pone.0092072

Akobundu IO (1987) Weed science in the tropics: principles and practices. Wiley and Sons, Chichester, UK

Akobundu IO, Agyakwa CW (1987) A handbook of West African weeds. International Institute of Tropical Agriculture, Ibadan, Nigeria

Arodokoun DY, Tamò M, Cloutier C, Adeoti R (2003) Importance of alternative host plants for the annual cycle of the legume pod borer, Maruca vitrata Fabricius (Lepidoptera: Pyralidae). Int J Trop Insect Sci 23:103-113

Atachi P, Djihou ZC (1994) Record of the host plants of Maruca testulalis (Geyer) (Lepidoptera: Pyralidae) in the Republic of Benin. Ann Soc Entomol Fr 30:169-174

Ba NM, Margam VM, Dabire-Binso CL, Sanon A, McNeil J, Murdock LL, Pittendrigh BR (2009) Seasonal and regional distribution of the cowpea pod borer, Maruca vitrata Fabricius (Lepidoptera: Crambidae), in Burkina Faso. Int J Trop Insect Sci 29:109-113

Ba NM, Huesing JE, Dabiré-Binso CL, Tamò M, Pittendrigh BR, Murdock LL (2019) The legume pod borer, Maruca vitrata Fabricius (Lepidoptera: Crambidae), an important insect pest of cowpea: a review emphasizing West Africa. Int J Trop Insect Sci 39:93-106. https://doi.org/10.1007/s42690-019-00024-7

Bett B, Gollasch S, Moore A, James W, Armstrong J, Walsh T, Harding R, Higgins TJV (2017) Transgenic cowpeas (Vigna unguiculata $\mathrm{L}$. Walp) expressing Bacillus thuringiensis Vip3Ba protein are protected against the Maruca pod borer (Maruca vitrata). Plant Cell Tiss Org 131:335-345. https://doi.org/10. 1007/s11240-017-1287-3

Bottenberg H (1995) Farmer's perceptions of crop pests and pest control practices in rainfed cowpea cropping systems in Kano, Nigeria. Int J Pest Manag 41:195-200

Bottenberg H, Tamò M, Arodokoun DY, Jackai LEN, Singh BB, Youm O (1997) Population dynamics and migration of cowpea pests in Northern Nigeria: implications for integrated pest management. In: Singh BB, Mohan Raj DR, Dashiell KE, Jackai LEN (eds) Advances in cowpea research. Copublication of International Institute of Tropical Agriculture (IITA) and Japan International Research Center for Agricultural Sciences (JIRCAS), IITA, Ibadan, Nigeria, pp 271-284

Campagne P, Peter E, Smouse PE, Pasquet R, Jean-François SJF, Le Ru B, Van den Berg J (2016) Impact of violated high-dose refuge assumptions on evolution of Bt resistance. Evol Appl 9:596-607

Carrière Y, Crowder DW, Tabashnik BE (2010) Evolutionary ecology of insect adaptation to Bt crops. Evol Appl 3:561-573. https://doi.org/10.1111/j.1752-4571.2010.00129.x

Ekesi S (1999) Insecticide resistance in field populations of the legume pod-borer, Maruca vitrata Fabricius (Lepidoptera: Pyralidae) on cowpea, Vigna unguiculata (L.), Walp in Nigeria. Int J Pest Manag 45:57-59

Fatokun CA (2002) Breeding cowpea for resistance to insect pests: attempted crosses between cowpea and Vigna vexillata. In: Fatokun CA, Tarawali SA, Singh BB, Kormawa PM, Tamò M (eds) Challenges and opportunities for enhancing sustainable cowpea production. International Institute of Tropical Agriculture (IITA), Ibadan, Nigeria, pp 52-61

Gould F (1998) Sustainability of transgenic insecticidal cultivars: integrating pest genetics and ecology. Annu Rev Entomol 43:701-726

Greig-Smith P (1983) Quantitative plant ecology, 3rd edn. Blackwell Scientific Publications, Oxford, England

Head GP, Greenplate J (2012) The design and implementation of insect resistance management programs for Bt crops. GM crops \& Food. Biotechnology in Agriculture and the Food chain 3:144-153. https://doi.org/10.4161/gmcr.20743

Huang FN, Andow DA, Buschman LL (2011) Success of the high-dose/ refuge resistance management strategy after 15 years of Bt crop use in North America. Entomol Exp Appl 140:1-16

Jackai LEN, Adalla CB (1997) Pest management practices in cowpea: a review. In: Singh BB, Mohan Raj DR, Dashiell KE, Jackai LEN (eds) Advances in cowpea research. Copublication of International Institute of Tropical Agriculture (IITA) and Japan International Research Center for Agricultural Sciences (JIRCAS), IITA, Ibadan, Nigeria, pp 240-258

Jackson RE, Bradley JR, van Duyn J, Leonard BR, Allen KC (2008) Regional assessment of Helicoverpa zea populations on cotton and non-cotton crop hosts. Entomol Exp Appl 126:89-106. https://doi.org/10.1111/j.1570-7458.2007.00653.x

Jepson PC, Guzy M, Blaustein K, Sow M, Sarr M, Mineau P, Kegley $S$ (2014) Measuring pesticide ecological and health risks in West African agriculture to establish an enabling environment for sustainable intensification. Philos T R Soc B 369(1639):20130491

Margam V, Ibrahim B, Ba NM, Ishiyaku MF, Huesing JE, Pittendrigh BR, Murdock LL (2010) Wild host plants of legume pod borer Maruca vitrata (Lepidoptera: Pyralidae: Crambidae) in southern Niger and northern Nigeria. Inter J Trop Insect Sci 30:108-114. https://doi.org/10.1017/S1742758410000123

National Biosafety Management Agency (NBMA), Nigeria (2019) Decision Document for a permit for the Commercial release of Pod Borer - Resistant Cowpea (PBR - Cowpea)-event AAT709A, genetically modified for lepidopteran insect pest (Maruca vitrata) resistance, issued to Institute for Agricultural Research (IAR), Zaria. Available from https://nbma.gov.ng/wp-content/uploads/ 
2017/11/Decision-Document-for-Commercial-Release-of-PBRCowpea-2019-final.pdf

Onstad DW, Kang J, Ba NM, Tamò M, Jackai LEN, Dabire CL, Pittendrigh BR (2012) Modeling Evolution of Resistance by Maruca vitrata (Lepidoptera: Crambidae) to Transgenic Insecticidal Cowpea in Africa. Environ Entomol 41(5):12551267. https://doi.org/10.1603/EN11172

Roush RT (1997) Bt-transgenic crops: just another pretty insecticide or a chance for a new start in resistance management? Pestic Sci 51:328-334

Sharma HC, Saxena KB, Bhagwat VR (1999) The legume pod borer, Maruca vitrata: bionomics and management. Information bulletin 55, International Crops Research Institute for the Semi-Arid Tropics (ICRISAT), Patancheru, India. http://oar.icrisat.org/ 6608/1/IB\%20no\%20\%2055.pdf

Singh SR, Jackai LEN, Dos Santos JHR, Adalla CB (1990) Insect pests of cowpea. In: Singh SR (ed) Insect pests of tropical food legumes. John Wiley and Sons Ltd., Chichester, U.K., pp 43-90

Storer NP, Babcock JM, Schlenz T, Meade G, Thompson D, Bing JW, Huckaba RM (2010) Discovery and characterization of field resistance to Bt maize: Spodoptera frugiperda (Lepidoptera: Noctuidae) in Puerto Rico. J Econ Entomol 103:1031-1038

Tabashnik BE, Van Rensburg JBJ, Carrière Y (2009) Field-Evolved Insect Resistance to Bt Crops: definition, theory, and data. J Econ Entomol 102(6):2011-2025

Tamò M, Arodokoun DY, Zenz N, Tindo MC, Agboton C, Adeoti R (2002) The importance of alternative host plants for the biological control of two main cowpea insect pests, the pod borer, Maruca vitrata (Fabricius) and the flower thrips, Megalurothrips sjostedti (Trybom). In: Fatokun CA, Tarawali SA, Singh BB, Kormawa PM, Tamò M (eds) Challenges and opportunities for enhancing sustainable cowpea production. Proceedings of the 3rd World Cowpea Conference, 5-10 September 2000, Ibadan, Nigeria, pp. 81-93. https:// books.google.com/books?hl=en\&lr=\&id=0hTzTEHixz0C\& $\mathrm{oi}=$ fnd \&pg $=$ PR $1 \& \mathrm{dq}=$ )+Challenges+and+opportunities + for + enhancing +sustainable+cowpea+production.+Proceedings + of +the+3rd+World+Cowpea+Conference \&ots=wbT48j2ldu\& sig $=$ e3FUm3nry578P0x Qnk05q1H2T00\#v=onepage $\& \mathrm{q}=) \%$ 20 Challenges $\% 20$ and $\% 20$ opportunities $\% 20$ for $\% 20$ enhancing $\%$ 20sustainable $\% 20$ cow pea\% 20 production. $\% 20$ Proceedings $\%$ 20 of $\% 20$ the $\% 203$ rd $\% 20$ World $\% 20$ Cowpea $\% 20$ Conference $\& \mathrm{f}=$ false

Traore F, Ba NM, Dabire-Binso CL, Sanon A, Pittendrigh BR (2014) Annual cycle of the legume pod borer Maruca vitrata Fabricius (Lepidoptera: Crambidae) in southwestern Burkina Faso. Arthropod-Plant Interactions 8:155-162. https://doi.org/10.1007/ s11829-014-9297-0

Vacher C, Bourguet D, Rousset F, Chevillon C, Hochberg ME (2003) Modelling the spatial configuration of refuges for a sustainable control of pests: a case study of Bt cotton. J Evo Bio 16:378-387

Van Rensburg JBJ (2007) First report of field resistance by the stem borer, Busseola fusca (Fuller) to Bt-transgenic maize. S Afr J Plant Soil 24:147-151. https://doi.org/10.1080/02571862.2007.10634798 